\title{
How to Prepare MSMES Financial Reports?
}

\section{Hedy Rumambi, Revleen Kaparang, Sintje Alouw, Ivoletti Walukow, Lusye Kumaat}

To Link this Article: http://dx.doi.org/10.6007/IJARBSS/v11-i11/11682

DOI:10.6007/IJARBSS/v11-i11/11682

Received: 13 September 2021, Revised: 18 October 2021, Accepted: 05 November 2021

Published Online: 19 November 2021

In-Text Citation: (Rumambi et al., 2021)

To Cite this Article: Rumambi, H., Kaparang, R., Alouw, S., Walukow, I., \& Kumaat, L. (2021). How to Prepare MSMES Financial Reports? International Journal of Academic Research in Business and Social Sciences, 11(11), 2131-2139.

\section{Copyright: (c) 2021 The Author(s)}

Published by Human Resource Management Academic Research Society (www.hrmars.com)

This article is published under the Creative Commons Attribution (CC BY 4.0) license. Anyone may reproduce, distribute, translate and create derivative works of this article (for both commercial and non0-commercial purposes), subject to full attribution to the original publication and authors. The full terms of this license may be seen at: http://creativecommons.org/licences/by/4.0/legalcode

Vol. 11, No. 11, 2021, Pg. $2131-2139$

Full Terms \& Conditions of access and use can be found at http://hrmars.com/index.php/pages/detail/publication-ethics 


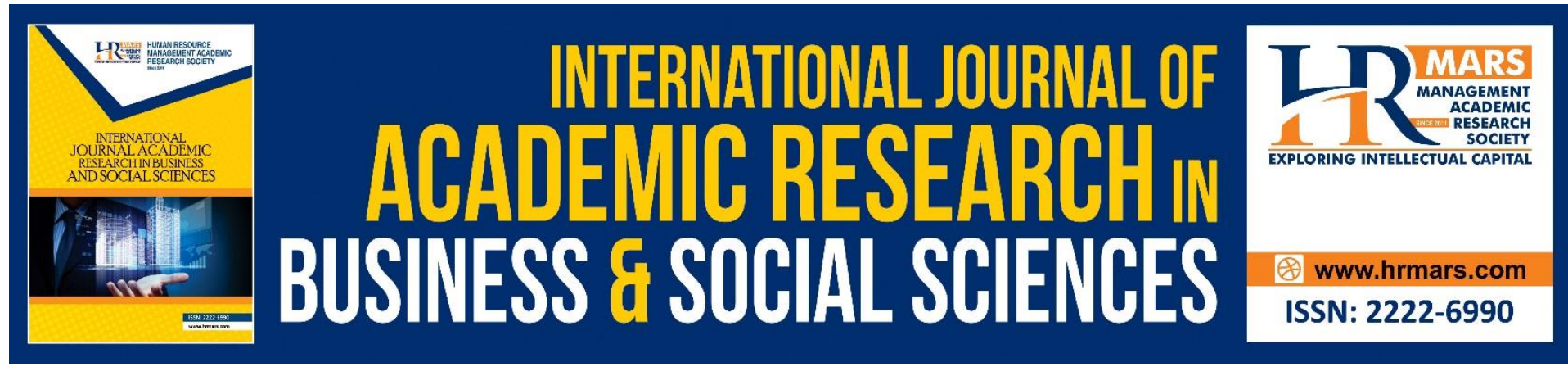

\title{
How to Prepare MSMES Financial Reports?
}

\author{
Hedy Rumambi, Revleen Kaparang, Sintje Alouw, Ivoletti \\ Walukow, Lusye Kumaat \\ Manado State Polytechnic, Polytechnic Highway Buha Village, Manado, Indonesia \\ Email: hedydr@yahoo.com (Corresponding author)
}

\begin{abstract}
Companies including MSMEs need to prepare financial reports to determine their financial position and business performance. Currently, there are still many MSMEs in Indonesia that have not prepared financial reports especially the micro-scale businesses. This study aimed to describe the preparation of MSMEs financial reports. This study used a qualitative research design with a case study method on the walnut dodol business in the city of Manado. The data were collected through in-depth interviews with business owners, document observations, and literature studies. Data analysis was carried out with the stages of data reduction, data presentation, and drawing conclusions on the preparation of MSME financial reports. The results of the study showed that to prepare financial statements, it is necessary to identify MSME business activities and financial transactions. Next, the researcher identified the accounts related to these financial transactions. The identification results were used to classify and describe the elements of financial statements. The elements of financial statements include assets, equity, income, and expenses. The description of the elements in the MSME financial position report includes cash, trade receivables, supplies of raw materials (palm sugar, coconut milk, spices, flour, walnuts), supplies of auxiliary materials (shells, woka leaves, and mica) and owner's capital. The income statement includes net income from dodol sales and operating costs such as raw material costs, auxiliary materials costs, transportation costs, electricity costs and salary costs.
\end{abstract}

Keywords: MSMEs, Accounting System, Financial Report

\section{Introduction}

The financial information presented in the financial reports shows the ability of MSMEs in financial management and performance achievement. Research conducted in various regions in Indonesia found that there are many MSMEs not compiling financial reports (Mandey et al., 2018; Rohendi, 2019; Uno et al., 2019; Simanjuntak et al., 2020; Risal and Wulandari, 2021). The presence of Financial Accounting Standards for MSMEs in Indonesia should be a reference in preparing financial reports but cannot bridge the needs of business actors due to their limited knowledge. The standard only provides general reference concepts but does not explain the process of preparing financial statements (practical level). Besides that, the business characteristics of MSMEs are different so that the elements in the financial statements are also different (Rumambi et. al., 2019a; Rumambi et al., 2019b). Therefore, MSMEs need a practical model as a reference in preparing their financial statements. 
Based on the initial survey conducted by researchers, the dodol walnut business owners have not kept financial records properly. Financial records are carried out in the form of income and expense records. MSMEs do not make financial reports so that their business performance is not measured reliably. Based on the real conditions of MSMEs, this research aimed to describe the preparation of financial reports based on Dodol Walnuts MSMEs data. The specific objectives: 1) to identify the business activities; 2) to identify the financial transactions; 3 ) to present the elements of the financial reports; 4) to prepare financial reports. This practical model is needed because MSMEs owners have the limited knowledge in preparing financial reports.

\section{Methods}

This study used a qualitative research design. The research method was a case study on MSME dodol walnuts in Manado city. The data were collected through in-depth interviews with business owners, document observations, and literature studies. The data needed includes business activities, financial transactions, and financial records carried out by MSMEs. Furthermore, researchers conducted a literature study to collect concepts/theories for preparing financial reports and previous studies.

Data analysis was carried out with data reduction, data presentation, and drawing conclusions (Miles et al., 2014). Data reduction was carried out in the process of identifying business activities, financial transactions and accounts relevant to the transactions. After that, the data were presented based on the elements of the financial reports and the conclusions were drawn in the form of a description of the elements used in preparing the financial reports.

\section{Results and Discussion}

\section{MSMEs Business Activities}

Walnut dodol business is a business that has been carried out for generations from the parents of the business owner. Currently, walnut dodol customers are not only from Manado but also from various regions in Indonesia. Walnut dodol is one of the most popular souvenirs from Manado.

The production activities of this business are based on orders. Customers must order first because this product only last a maximum of 3 days outside the refrigerator. The production process is simple and only done by family members. They do not use labor with monthly payroll. MSME business management is carried out simply and only involves family members. Financial recording is carried out in recording sales/orders and costs spent related to the production process.

\section{Financial Transaction of MSMEs}

Transactions during one reporting period include transactions for depositing owner's capital, receipts from sales, expenditure transactions and transactions of materials for the production process. Expenditure transactions include the purchase of palm sugar, coconut milk, spices, flour, walnuts, shells, woka leaves and mica as well as expenses for business operations such as transportation costs, electricity, and salaries. Transactions on the use of materials include the use of palm sugar, coconut milk, spices, flour, walnuts, shells, woka leaves, and mica. 


\section{The Elements of Financial Report}

The elements of financial reports according to Financial Accounting Standards (2018) include assets, liabilities, equity, income and expenses. Assets are a form of entity's wealth in the form of resources control as a result of past events and the future economic benefits are expected to flow to the entity. Liabilities are obligations of the entity at a certain date that arise from past events and the settlement of the results in an outflow from the entity resources. Equity represents ownership of the entity assets after deducting all liabilities. Income is the addition of economic benefits in a certain period caused by an increase of the assets or a decrease in liabilities. Expenses are economic benefits that decrease in a certain period and associated with a decrease in assets or an increase in liabilities.

According to SFAC no. 6, certain entity resources, claim of resources and transaction impact and other occasion can change the resource and the claim represented in the elements of financial reports (FASB, 2008). In preparing the financial reports, the five elements are described in more detail in various financial statement accounts. Each account of the elements must be able to represent accounting information accurately from the phenomenon to be presented.

To prepare financial reports, MSME actors need to understand five elements of financial reports. The elements of financial reports as standardized in accounting standards for MSMEs are still general. The different characteristics of MSME businesses cause the account formation of each element in the financial reports to be different according to the scope of business, business activities and financial transactions. To accurately represent the phenomena that exist in the entity, the formation of accounts from these elements refers to the business characteristics of the entity.

Rumambi et al (2020) states that the transactions occurs become the basis for building financial statement accounts. These accounts become the basis for recording and classifying transactions. The design of the account name is based on financial transactions in MSMEs (Rumambi et al., 2019b). 
Table 1 Identification of Accounts Used Based on Financial Transactions

\begin{tabular}{|c|c|c|}
\hline Business Activity & Transaction & Used Account \\
\hline \multirow[t]{23}{*}{ Dodol Production } & $\begin{array}{l}\text { Receipt and disbursement of } \\
\text { money }\end{array}$ & Cash \\
\hline & Purchasing palm sugar & $\begin{array}{l}\text { Palm sugar raw material } \\
\text { supplies }\end{array}$ \\
\hline & Purchase of coconut milk & $\begin{array}{l}\text { Supply of coconut milk raw } \\
\text { materials }\end{array}$ \\
\hline & Purchase of spices & $\begin{array}{l}\text { Inventory of raw materials } \\
\text { for spices }\end{array}$ \\
\hline & Purchase of flour & $\begin{array}{l}\text { Inventory of flour raw } \\
\text { materials }\end{array}$ \\
\hline & Walnut purchase & $\begin{array}{lll}\text { Walnut raw material } \\
\text { inventory }\end{array}$ \\
\hline & Purchase of shell & $\begin{array}{l}\text { Inventory of shell auxiliary } \\
\text { materials }\end{array}$ \\
\hline & Purchase of woka leaves & $\begin{array}{l}\text { Supplies of woka leaf } \\
\text { auxiliary materials }\end{array}$ \\
\hline & Purchase of mica & $\begin{array}{l}\text { Supplies of mica auxiliary } \\
\text { materials }\end{array}$ \\
\hline & Dodol sales on credit & Account receivable \\
\hline & Capital deposit by owner & Owner's Capital \\
\hline & Dodol sales & Sale \\
\hline & Use of palm sugar & $\begin{array}{l}\text { Palm sugar raw material } \\
\text { costs }\end{array}$ \\
\hline & Use of coconut milk & $\begin{array}{l}\text { Coconut milk raw material } \\
\text { cost }\end{array}$ \\
\hline & Use of spices & $\begin{array}{l}\text { Cost of raw materials for } \\
\text { spices }\end{array}$ \\
\hline & Use of flour & Flour raw material cost \\
\hline & Use of walnuts & Walnut raw material cost \\
\hline & Use of shell & $\begin{array}{l}\text { Cost of shell auxiliary } \\
\text { materials }\end{array}$ \\
\hline & Use of woka leaves & $\begin{array}{l}\text { Cost of woka leaf auxiliary } \\
\text { materials }\end{array}$ \\
\hline & Use of mica & $\begin{array}{l}\text { Cost of mica auxiliary } \\
\text { materials }\end{array}$ \\
\hline & $\begin{array}{l}\text { Payment of transportation } \\
\text { costs }\end{array}$ & Transportation costs \\
\hline & Electricity token payment & Electricity cost \\
\hline & Payroll & Salary expense \\
\hline
\end{tabular}

Source: Processed Data, 2021

Table 1 describes the identification results of financial transactions that occur so that an account can be formed to be used in the process of preparing financial reports. The formation of these accounts is an element of the concept that underlies the preparation of financial 
reports (Rumambi et al, 2020). The identification results in table 1 were classified into five elements so that the accounts become a description of each element of the financial reports.

Table 2 Classification and Description of MSMEs Financial Report Elements

\begin{tabular}{|c|c|c|}
\hline Financial Reports & $\begin{array}{l}\text { Elements of Financial } \\
\text { Reports }\end{array}$ & $\begin{array}{c}\text { Description of MSMEs } \\
\text { Financial Reports Elements }\end{array}$ \\
\hline \multirow{11}{*}{$\begin{array}{l}\text { Financial Position } \\
\text { Report }\end{array}$} & \multirow[t]{10}{*}{ Asset } & Cash \\
\hline & & Account receivable \\
\hline & & $\begin{array}{l}\text { Palm sugar raw material } \\
\text { supplies }\end{array}$ \\
\hline & & $\begin{array}{l}\text { Supply of coconut milk raw } \\
\text { materials }\end{array}$ \\
\hline & & $\begin{array}{l}\text { Inventory of raw materials } \\
\text { for spices }\end{array}$ \\
\hline & & $\begin{array}{l}\text { Inventory of flour raw } \\
\text { materials }\end{array}$ \\
\hline & & $\begin{array}{l}\text { Walnut raw material } \\
\text { inventory }\end{array}$ \\
\hline & & $\begin{array}{l}\text { Inventory of shell auxiliary } \\
\text { materials }\end{array}$ \\
\hline & & $\begin{array}{l}\text { Supplies of woka leaf } \\
\text { auxiliary materials }\end{array}$ \\
\hline & & $\begin{array}{l}\text { Supplies of mica auxiliary } \\
\text { materials }\end{array}$ \\
\hline & Equity & Owner's Capital \\
\hline \multirow[t]{12}{*}{ Income Report } & Income & Sale \\
\hline & Expense & $\begin{array}{l}\text { Palm sugar raw material } \\
\text { costs }\end{array}$ \\
\hline & & $\begin{array}{l}\text { Coconut milk raw material } \\
\text { cost }\end{array}$ \\
\hline & & $\begin{array}{l}\text { Cost of raw materials for } \\
\text { spices }\end{array}$ \\
\hline & & Flour raw material cost \\
\hline & & Walnut raw material cost \\
\hline & & $\begin{array}{l}\text { Cost of shell auxiliary } \\
\text { materials }\end{array}$ \\
\hline & & $\begin{array}{l}\text { Cost of woka leaf auxiliary } \\
\text { materials }\end{array}$ \\
\hline & & $\begin{array}{l}\text { Cost of mica auxiliary } \\
\text { materials }\end{array}$ \\
\hline & & Transportation costs \\
\hline & & Electricity cost \\
\hline & & Salary expense \\
\hline
\end{tabular}

Source: Processed Data, 2021 


\section{The Preparation of Financial Statement}

The financial report is a structured presentation of financial position and financial performance of an entity (Diana and Setiawati, 2017). Financial reports serve as a means to convey financial information to parties outside the company (Kieso et al., 2017). This financial information is useful for users in creating economic decisions (Okoye and Akenbor, 2014).

To prepare financial reports, entities should consider the concept of a business entity as their basic premise. For individual businesses, entities need to make a clear separation between business owners and business entities so that owner transactions are separate from entity business transactions (Financial Accounting Standards, 2018). From this entity concept flows the need for financial reporting. In order for the accounting information submitted in the financial reports to be useful, the information needs to be presented relevantly, reliably, and consistently in the financial reports (Azim and Ara, 2015).

Based on financial accounting standards for MSMEs, the minimum financial reports consist of a statement of financial position at the end of the period, an income statement for the period, and notes to financial reports (Financial Accounting Standards, 2018). The statement of financial position provides information about the entity's assets, liabilities and equity as of a specific date. The income statement describes the achievement of the entities financial performance. Income and expenses during the reporting period are brought together to determine the results of performance achievements in the form of profit or loss. The notes to the financial reports describe the relevant details of the elements of the financial reports.

According to Rumambi et al (2020), there are three basic elements in preparing financial reports, namely forming elements, concept elements, and process elements. Forming elements are related to the efforts of researchers in exploring the activities and financial transactions of MSMEs. Concept elements are related to the formation of financial statement elements according to the characteristics of MSMEs. Process elements relate to the process to produce financial reports through the accounting cycle. The preparation of financial reports follows the process of the accounting cycle, namely from existing transactions, journals, ledgers and financial reports made (Rumambi et al., 2019b; Rumambi et al., 2020).

To prepare financial reports, MSMEs need to do it through one accounting cycle. The transactions that occur are analyzed and recorded in the journal according to the date of the transaction using the appropriate accounts according to the transactions that occurred and referring to table 1 . Then the recording of the journal will be transferred to the general ledger according to each account group. After all the records in the journal have been transferred to the general ledger, MSMEs calculate the balance of each ledger account. The balance of each general ledger account is then recorded in the trial balance. The purpose of making a trial balance is to control the suitability of the debit and credit balances of each ledger and ensure that the total debits and credits are the same. From the trial balance, MSMEs prepare financial reports.

The preparation of financial reports begins with the preparation of the income statement. The income statement is prepared by stating the amount of sales of dodol walnut during a certain period and then listing all costs incurred to be reconciled with the income. The calculation difference between income and costs, if the income is greater than costs, MSMEs will get profit and if income is less than costs, MSMEs will get loss. The results of the calculation of profit or loss describe the business performance achieved by MSMEs in that period. 
After the income statement is prepared, MSMEs make a statement of financial position. The preparation of the statement of financial position can be made in the form of a score (compiled down) or in the form of a T account. MSMEs classify the elements in the financial reports on assets and capital according to table 2 . In the asset group, cash, receivables, and supplies of raw materials (palm sugar, coconut milk, spices, flour, walnuts) as well as supplies of auxiliary materials (shells, woka leaves, and mica). Each inventory account is presented separately. Based on the existing transactions there are no liability transactions so in the financial report it is stated as counterweight to assets is owner's capital. All balances and accounts in the trial balance must be included in the financial reports. The number of assets and the amount of capital included in the financial report position shows the total wealth of MSMEs and financial position for the period.

\section{Conclusion}

The preparation of MSME financial reports was carried out by considering the uniqueness of the scope and business activities of MSMEs. In preparing the financial reports, MSMEs need to identify the financial transactions occurs, form accounts, and group them into elements of financial reports. Furthermore, the process of preparing financial reports was carried out by following the accounting cycle. MSMEs record the financial transactions into journals and post them to the general ledger. After that, a trial balance is prepared as the basis for preparing financial reports. MSME reports according to Financial Accounting Standards consist of financial position reports, income reports and notes to financial reports. Given the limited ability, understanding and knowledge of MSME owners, it is recommended that financial reports can be prepared only in the form of income reports and the financial position reports.

The results of this study provides a practical impact for micro-scale MSME business actors in preparing their financial reports. The implementation model of this research will be a practical guide for MSMEs. The limitation of this research is the practical model built from MSMEs that have business activities in the production of walnut dodol. For this reason, further research can be carried out in other business fields. Financial reports and their elements characterize the unique characteristics of an entity.

\section{Acknowledgments}

The research team would like to thank to the Manado State Polytechnic through the Center for Research and Community Service for funding this research. Research team also thanks to MSMEs who have provided time and data for this research.

\section{References}

Azim, M., \& Ara, J. (2015). Accountability of accounting stakeholders. Global Journal of Management and Business Research, 15 (2), 4-10.

Diana, A., \& Setiawati, L. (2017). Intermediate financial accounting. Yogyakarta:Andi.

Financial Accounting Standards Board. (2008). Statement of financial accounting concepts no.

6 elements of financial statements. https://www.fasb.org/jsp/FASB/Document_C/

Institute of Indonesia Chartered Accountants. (2018). Financial Accounting Standards for Micro, Small, and Medium Entities, Jakarta: IAI.

Kieso, D. E., Weygandt, J. J., \& Warfield, T. D. (2017). Intermediate Financial Accounting, IFRS

Edition. Volume 1. Jakarta: Salemba Empat. 
Mandey, M. J., Saerang, D. P. E., \& Pusung, R. J. (2018). Qualitative study of the benefits and disadvantages in the preparation of financial statements on UD Mitra Pelita. Journal of Accounting Research Going Concern, 3 (2), 589-598.

Miles, M. B., Huberman, A. M., \& Saldana, J. (2014). Qualitative data analysis: A methods source book, Edition 3, Sage Publication Inc.

Okoye, P. V. C., \& Akenbor, C. O. (2014). Financial reporting framework in Nigeria and the adoption of the international financial reporting standards. International Journal of Business and Economic Development, 2 (1), 52-63.

Risal and Wulandari, R. (2021). Analysis of accounting application in MSMEs in the city of Pontianak. Journal of Accounting and Business Research, 7(1), 14-26.

Rumambi, H., Kaparang, R., Lintong, J., \&Tangon, J. (2019a). The building blocks to construct financial statements of micro, small, and medium enterprises (MSMEs) of rice farmers groups. International Journal of Academic Research in Accounting, Finance and Management Sciences, 9(4), 1-9.

Rumambi, H. D., Kaparang, R. M., Lintong, J. S., \& Tangon, J. (2019b). Preparation of financial statements. Manado: Polimdo-Press.

Rumambi, H., Kaparang, R., Lintong, J., \& Tangon, J. (2020). Explores the basic elements of preparing MSMES financial statements for agricultural entities. International Journal of Academic Research in Accounting Finance and Management Sciences, 10(3), 502-509.

Simanjuntak, N. H., Sumual, T. E. M., \& Bacilius, A. (2020). Preparation of MSME financial reports based on SAK-EMKM (Case Study on Restoran Delli Tomohon). JAIM: Accounting Journal Manado, 1(3), 35-44.

Rohendi, H. (2019). Analysis of the implementation of the preparation of financial reports on MSMEs based on Financial Accounting Standards for MSMEs. Proceedings National Seminar and Call for Papers "Sustainable Development of Rural Resources and Local Wisdom IX" 19- 20 November 2019 Purwokerto, 86-98.

Uno, M. O., Kalangi, L., \& Pusung, R. J. (2019). Analysis of the application of Financial Accounting Standards for MSMEs in Micro, Small, and Medium Enterprises (Case Study on Karawo House in Gorontalo City). EMBA Journal, 7(3), 3877 - 3898 